\title{
Emblemas do tempo: imagens sobre a passagem do século XIX para o XX na imprensa carioca
}

\author{
Emblems of time: images in \\ the Rio de Janeiro press from the \\ turn of the 20th century
}

\begin{abstract}
"À meia-noite de hoje assistirá quem viver ao expiar do século XIX e ao raiar clo século XX. ... Que se vai passar logo à meia-noite? Demonstrará, porventura, a natureza, de alguma forma, a sua participação no phenomeno? Brilharão mais fortes os astros? Fará a lua uma apparição excepcional, fora do programa? Haverá, em suma, nos domínios eterológicos, algum sinal do grande acontecimento universal que se vai realizar?" ( O Paiz, 31.12.1900).
\end{abstract}

C uriosa em saber como os cariocas vivenciaram a passagem para o século XX, fui aos jornais e revistas que povoaram o cotidiano urbano da capital federal, e estas fontes revelaram-se ideais para saciar minha curiosidade. Consultei vários títulos em busca de uma iconografia que me figurasse as impressões do passar do tempo, cadenciado pelo calendário gregoriano que modelou os hábitos ocidentais.

Foi com surpresa que encontrei tantas imagens visuais e escritas nos diários e semanários publicados em 1899, 1900 e 1901: crônicas, fotografias, caricaturas, ilustrações, calendários e até os formulários do recenseamento feito em 31 de dezembro de 1900. São emblemas de um tempo que cumpria seu rito de finalização, compondo um mosaico que tento reproduzir neste ensaio.

Medos, expectativas, ansiedades, balanços do que se fora, propostas para o porvir o cotidiano tratado como comédia e, ainda, a relativização do rito, sugerindo a idéia de que, no final das contas, era apenas mais um dia que se ia e outro que chegava. São estas as principais facetas do tempo retratado pela lente dos fotógrafos e pela pena clos caricaturistas, cronistas e articulistas da imprensa carioca. Esta deu grande destaque às festas religiosas e profanas celebradas na ocasião. E debateu exaustivamente um tema que volta a mobilizar aqueles que se preparam para encerrar o milênio: quando, exatamente, começava o novo século, 1900 ou 1901?

A princípio, eu pretendia avaliar a figuração do tempo futuro usando, também, ícones da modernização, como exposições nacionais e internacionais, maquinismos associados ao cotidiano e ao lazer etc. No entanto, ampliaria por demais o leque de 
representações, distendendo o sentido específico do rito de mudança. Preferi, então, discutir a data e os fatos a ela relacionado como pontas de icebergs. ${ }^{1}$

\section{Problemas da cronologia}

A data exata do início de um novo século ainda provoca confusão. O filme Strange Days, ${ }^{2}$ por exemplo, ambienta sua trama de ficção científica na passagem do século XX para o XXI, só que a festa de ano-novo ocorre no último dia de 1999.

Erros como esse foram cometidos há cem anos. A revista D. Quixote (ano V, no 109, 30.12.1899, p. 2) comemorou a passagem para os novecentos no último dia de 1899: "Chegaremos ao fim do ano e, segundo alguns, ao fim d'este século ... . Boas festas e grande felicidade no ano novo e novo século de 1900 ".

Não faltaram correções ao tropeço cronológico, o que obrigou a revista a tornar pública a discussão: "Entramos ou não no século XX?" - indagava.

Há várias opiniões; uns dizem que sim e outros que não.

Esta divergencia dá-se 3/4 quem diria! 3/4 entre as próprias sumidades científicas e sobre uma questão puramente de cálculo, que, assim como a matemática, é tudo quanto pode haver de mais positivo e certo. ... Este ano começa, portanto, trazendo-nos uma séria complicação, o que prova que nada há certo e positivo n'este mundo, nem mesmo as matemáticas. ... Há, portanto, dois modos de contar e de somar. Tudo depende do ponto de partida e da colocação dos algarismos; 3 e 2 são 5 , assim como podem ser 32 ou 23.

N'esta questão do século XX uns começam a contá-lo desde o primeiro segundo, minuto, hora e dia do ano $1^{2}$ e outros tomam este como unidade. Por aí vê-se que as tais ciências positivas deixaram de o ser, e estão hoje tão embrulhadas como tudo quanto há n'este mundo" ( $D$. Quixote, ano VI, $\mathrm{n}^{2} 110,6.1 .1900$, p. 3).

Diversas autoridades foram consultadas sobre aquele impasse científico. A edição de 1900 do Almanaque Laemmert (ano V, $\mathrm{n}^{0} 109,30.12 .1899$, pp. 2-5) teve o cuidado de introduzir em seu calendário a seguinte nota:

"O século XX (quando começa?)

O dr. Beuf, diretor do Observatório de La Plata, respondendo a esta pergunta, disse:

A meu juízo e de conformidade com as regras adotadas, o século atual, que começou a $1^{2}$ de janeiro de 1801, deve forçosamente terminar em 31 de dezembro de 1900, o que está de acordo com a definição de século que diz ir de 1 a 100 e não de 0 a 99 .... Não houve século 0 . Os astrônomos designam somente pelo século zero o que precedeu o primeiro século da era cristã". (p. 5)

No entanto, a ciência não satisfez a aqueles que, como o cronista da revista $D$. Quixote, encaravam as comemorações de calendário como meras convenções que demarcavam a passagem não apenas dos anos e séculos como das dívidas e despesas:

\footnotetext{
${ }^{1}$ Bosı, Alfredo, O tempo e os tempos', em O olhar. São Paulo, Companhia das Letras, 1992, pp. 19-33.

2 Intitulado no Brasıl Estranbos Prazeres, é uma produção norte-amerıcana de 1995, dirigıda por Kathryn Bigelow, com Ralph Fiennes, Angela Basset, Tom Sizemore, entre outros.
} 
"Pois sim!... Boas festas, muito boas, não haja dúvida, em uma quadra destas, em que a maioria da populaçâo vive au jour le jour, em que quase todos tremem quando chega o fim do mês, por causa do aluguel e outras despesas; agora principalmente, no fim do ano, quando tudo se acumula, quando as notas e faturas chovem de todos os lados, e - oh, ironia! - misturadas com pedidos de festa." (ano V, $\mathrm{n}^{\mathrm{o}} 109,30.12 .1899$, p. 2).

Convenção ou não, a passagem do século foi gloriosamente festejada pelos cariocas. Na primeira página do Jornal do Brasil, de 2.1.1900, figura a imagem de um homem trôpego que diz: "Saí assim e entrei assim. Atirei-me às castanhas assadas com vontade, e as conseqüências são estas que aí estão vendo: as castanhas subiram-me até a cabeça."

\section{Festas}

As festas anunciadas nos jornais e revistas dividiram-se em laicas e religiosas. As mensagens veiculadas por clubes e agremiações configuram contraponto interessante com o predomínio das imagens religiosas. O aviso da festa, o brasão ou símbolo da sociedade carnavalesca e uma quadrinha de versos ou um breve texto dão sentido 'mundano' às comemorações.

Numa das publicidades mais audaciosas, o Clube dos Celibatários convidava para uma "arrochadíssima festa sem roupões", oferecida pelo "Grupo das Tentadoras", com direito a uma "eletrizadora recepção ao século XX, regada com pétalas de flores e champagne". O anúncio publicado na edição de 7.12 .1900 da Gazeta de Notícias era assinado pela "Abadessa Sulfurina".

Ao alardear seu "Cáustico e acintoso baile à fantasia em homenagem ao século XX", na edição matutina do Jornal do Brasil de 31.12.1900, o Clube dos Democráticos fazia uma miscelânia de imagens da tradição popular, embalando tudo com promessa de muita música.

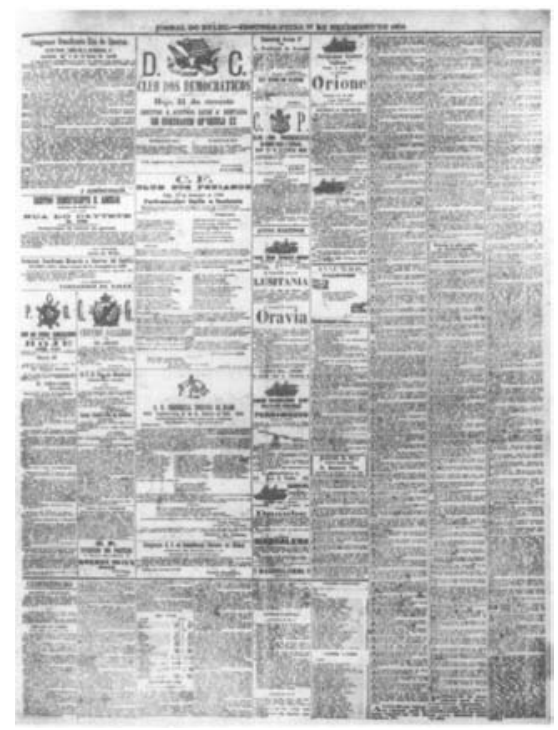

Jornal do Brasil, 31.12.1900.

O Clube dos Fenianos também convocava para um baile a fantasia, "soberba passagem, em plena folia, ao século das luminárias" (Gazeta de Notícias, 30.12.1900). Bailes igualmente "apoteóticos" eram preparados pelos Tenentes do Diabo, Club dos Estranguladores, Clube Nova Invenção, Congresso dos Políticos, Club do Campinho, Club do Riachuelo, G. D. Estudantina Apollo, Estudantina Arcas etc.

Por conta do Club Gymnastico Portuguez e do Recreio dos Artistas ficaram as comemorações mais familiares, condizentes com a sociedade conservadora que imaginamos para o final dos oitocentos: "Baile. Em 31 do corrente, para festejar a entrada do novo século, no qual tomará parte a nossa distinta banda de musica: ingresso às exmas. famílias." (Jornal do Brasil, edição matutina, 25.12.1900)

Enquanto os clubes promoviam festas animadas, a Igreja coordenava as comemorações públicas 


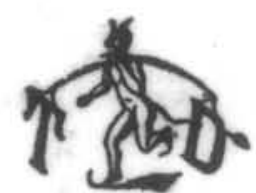

\section{B. COYHRRCHAL TRERTRS DO DISEO}

HOJE Segunda-feira, 91 de 8 . Silvestre de 1900 HONE subtimes fefereal o apparateno balte a fantahle

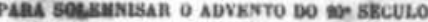

\section{TERENTES !}

Quando. 20 revolver da poeira đos serulos, atravez das paginas da bistorta, unas evoigelo

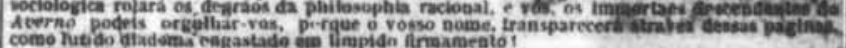

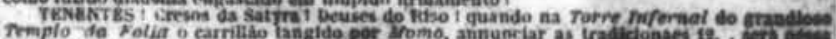

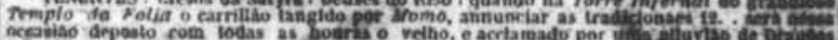

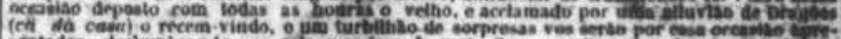

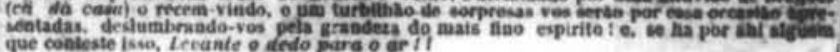

TENESTES:

Arante ! A frcunda lika

Tran-nos palmas $F$ inureist

Louros das eflorias atrave

Avante ao reahide preito,

O eafada rols decifeitoil

Num so mament" felia!
bepoit, da luta acabada

A Eloria fiea orvada.

Em rada uaus cicatrie!

e đepois diate ros direi aisda que,

Lutegost Fraces e fortes.

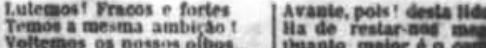

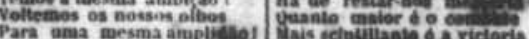
Lulem fortes, lutem fracos" guando o taturo obserto.

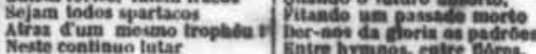
Yolte continus lutar mar K o mar se rolti pró civi

Cahirensos Yencesceres

\section{Sto arclamaçes ardentes}

que trin ece aniversal

Louver aos brayou Tenentes,

E por hoje basta de leria, o papel ceda yasqueiro, a tinta ef pouca e o jornal nos leva male alguns patacus : ate thes parem, nawavei, apois oihen que?

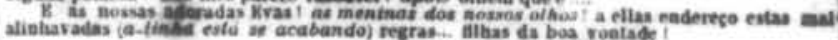
Mksivas !

Vob sols a encarnaclo of tudo quanto amamos

For isso c que hoje aqui, treneticos, de $\mathrm{pc}$.

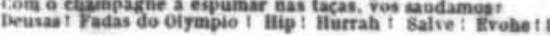

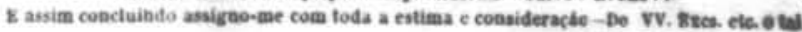

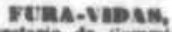

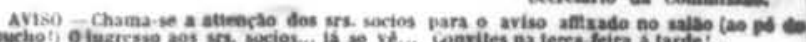

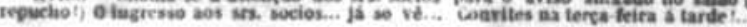

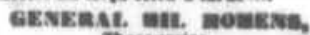
Thesoureiro.

Congresso B. H. a Conselheiro Farreira do Amaral SECRETARL, RU: GRERAL CAMARA $\mathrm{N}$. DS

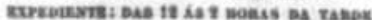

Terminando hoje, It do correate mes, a inscripcle de soclos fundadores, coanido todas

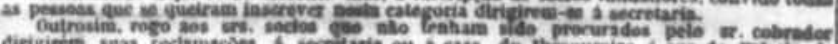

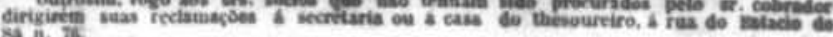

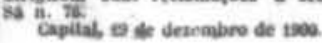

\section{Pealro Montelro,}

Sociedado Beneficente Memoria a Canovas del Castillo

SFCFET ARIA - Rua Lerga de S. deaguim n. 100

Convido os srs, associados a assistirem a sossao solemne que será effo-

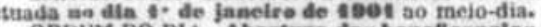

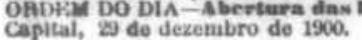

O 1. SECRETAIUO

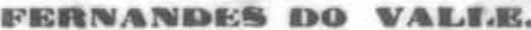

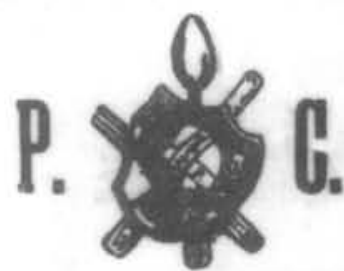

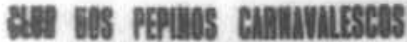
KNGENHO DB DENTRO

III D $\mathrm{E}$ GRACHE BAILE

oolemnemente reallitado para commemorar Seculo XX Dard ingresso ans urs. socios o exmo. car-

Br. Trinea Ferros. terat da noile.

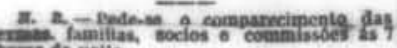
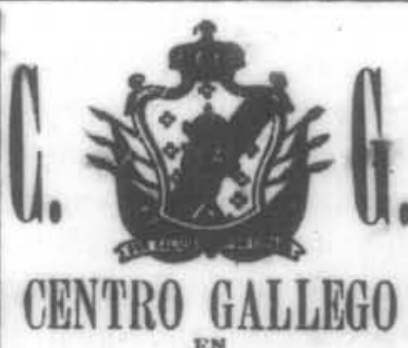

RIO JANEIRO

Tengo el guato de comunicar a los sres. nocios, que lioy, a las 9 de la noche se reali. del alfo y saluclar et ano nuevo. inviladones especiales en Secretaria.
bara incresso, a los socios el recibo de mio, $31-1 t-1300$

N) secretaria,

8. F. D. Floe da Mocidade gRemio bus vLones
Josk nobntoukz GABCa.

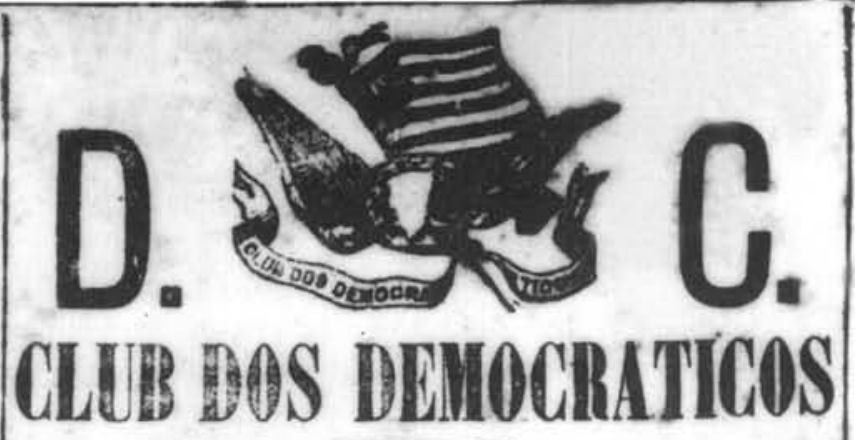

Hoje, 31 do corrente

\section{OAUSTICO E ACINTOSO BATLB A' TANTASLA BM HOMPIABM 10 8PRDLO IX}

A' meia-noite, y hora fatal, mysteriosa, caixas, elarins a bombos num barulto infernal,

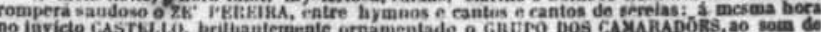

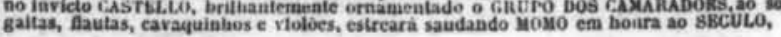

(6) SECUL. xax

Rasa for que are rouba sponpa e brithe F.

N. B,-Ingreswo com a thénourelro Tribca-Fintos.

PALADINO.

\section{F.}

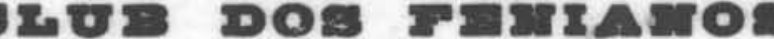

IIoje, 31 de dezembro de 1900

Ruri-secular bailo a fantasis

Soborba passagem em plena FOLIA ao seculo das IJIMINARIRS.

MONLMENTAL corrida A' LATA AOS POBHES DE ESPIUTO (sEM ALLUSTO AO D. C.)

Trveaves:

Logo que a noite comere Vinde ao Poleiro dourado, gub vorta a ifisteza. cesse

A vida 6 curto bocado.

Rem cedo desapparece:

Portanto, da diva ao tado Ber.1.As

Que ldes paviar ao seculo vindouro Ousindcosda Luarura an soma das tahaneras Ouvindo as harmobias das nessas rimas af Feslivarseumoos sons đas mseis pu imaverast. Borboletas do amor, que em nowserres veaes:

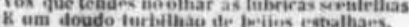
beswas boecas geulle, peyuenithas, verinelhas!

Pois entrar no sectlo novo. Como um prompio que suspira, So e proprio desse povi Denominado - - Di L. YнA * I

Povo baixo e salafrario, gue nato tando onde dormir Aos incautos imping

Povo que usa collarinho

Mas... que camisa nâo tem.

gue socaleja o bulsinb

Mas nem sombras de vintem,

- weenso petls

Com cara de misto - belle erianeintas

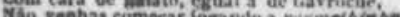
Nho' ventas te afogar nos tagos do debocho i se moderaqoe sćrio, assim cumoos hurguezes. Yansados de aturar duraste deze nueses.

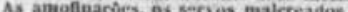

Termina a yuebradeira aus bancos tar ajuda. Todo o que podre ets, pive fora ou edeia, E Jus taras assim, a mais de uma epopeta ! Oue Morpheu venha contento, Rspallhar pelo ambiento Sonhos prenhes de desejost Nos bragos das Fenianas Cantie ao Iraser hosanas Entre harmonia de beijos t

Vinde, mais uma $\mathrm{rrz}$, provar desse remedio

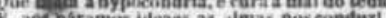

Ao Amor: Ao frazer ! llumalus ! pola volia I temettei a iristeza imberil que arrelia. seo wangres earapeten. Aces sia earapteine.

Que diz. que come pescada Mas, só arrota a safio, Ouer faca ealor ou frio.

Povo, emtlm, que anda tinhoso, Sendo a todos matipathice icudu mui pressuroso. Plo nothe de DEMockstico Mas tal povinho de lado Vamos pôr incontinente, E dar o nosso reeadio Ao que surgo pela vazsra!

Ama e seris amado. - A's bellas rapariga:

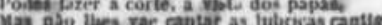
Measio silo de páo a sos solfrjarist

Inga. canta e dansa, a mnfiga es moderna. Fai os leus rapajes a lodas as peswoas.

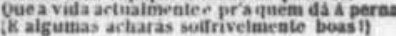

K para comvrar, $-\sigma$ sec le tentador!- ileilla crianca linura. - inirio dos ieus anenes

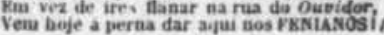
O 1* secretario, Agola.
Pro baile ser d'ostadiso

E so ter fente do ros, So da ingrosso o cartato Fornecido por 
e dominava as ruas da cidade, desde as freguesias centrais até as mais distantes. Isso deu à celebração da virada do século uma marca eminentemente religiosa, associada aos rituais católicos. As religiões afro-brasileiras sequer eram mencionadas pelos jornais, nem em notícias paralelas ao evento principal.

O Cidade do Rio, na edição de 31 de dezembro de 1900 , noticiou o roteiro organizado pelo arcebispo e avaliou a magnitude dos festejos:

"De todos os recantos do Brasil nos chegam notícias do modo pelo qual em cada cidade, vila ou arraial, se pretende solenizar a passagem do século... avultam pela excepcional solemnidade que lhe querem dar, os festejos religiosos ... para mostrar que o século que entra deve ser um século de repouso espiritual ..."

Na concepção do autor destas linhas, a humanidade "esvaída intelectualmente pelo trabalho torturado da análise científica ... com uma curiosidade que chegou até à alucinação", necessitava do conforto espiritual e da fé nos mistérios sagrados que só a Igreja católica lhes podia oferecer.

Toda a população foi convidada a iluminar as janelas com velas ou lampiões. Algumas residências e prédios comerciais já dispunham de energia elétrica, como a Associação dos Empregados do Comércio do Rio de Janeiro, que exemplo, iluminou a fachada de seu edifício com essa forma moderna de energia. Os capelães, párocos e reitores receberam a incumbência de anunciar o ritmo das atividades em 31 de dezembro através de "sinos e sinais festivos". As horas-chave seriam 18h; 00h e, no dia seguinte, 4h, meio-dia e $18 \mathrm{~h}$.

A celebração principal seria a procissão do Santíssimo Sacramento, para a qual a Igreja adotou ordenação sugestiva: os homens marchariam na dianteira, na ala das corporações religiosas, e as senhoras, depois do pálio. Ao chegarem à praça da Candelária, carregando velas, rodeariam os altares, guardando silêncio solene (Cidade do Rio, 31.12.1900). Dessa forma, teriam possibilidade de acompanhar o culto de qualquer ângulo. As flores, os cânticos, lamentos e ladainhas, combinados ao clarão das velas que iam arder num sem-número de mãos conformariam uma atmosfera mágica.

A Companhia de Bondes São Cristovão anunciou em todos os jornais que faria circular, durante a noite do dia 31, carros extraordinários em todas as suas linhas. Como forma, também, de arregimentar o maior número de fiéis, o arcebispo enviou circular às paróquias e irmandades, em 27 de dezembro, dispensando-as de atos para comemorar o final do século.

$O$ roteiro anunciado pelo arcebispo concentrava todas as solenidades na catedral metropolitana, a Igreja da Candelária, e em suas imediações. De acordo com a matéria do jornal, as atividades iam começar às $18 \mathrm{~h}$ de 31 de dezembro, com missa, seguida de procissão de Ação de Graças pelas ruas Primeiro de Março, Carmo, Ouvidor, Sete de Setembro e pelo Largo do Paço. À meia-noite, na catedral, a nova cruz comemorativa seria benzida, iniciando-se, então, o Te-Deum. A partir deste ato, cânticos, orações e bênçãos seriam entoados pela noite adentro em altares nos quatro ângulos da praça contígua à catedral, representando cada um o Oriente, o Meio-dia, o Ocidente e o Setentrião. Tinham sido construídos a expensas do visconde de São Cosme Velho, que custeara toda a ornamentação da praça.

A edição de 6.1.1901 da Revista da Semana, publicação do Jornal do Brasil, traz na primeira página sete imagens das comemorações, acompanhadas de artigo cujo autor 
indagava sobre as perspectivas do novo século. As imagens ainda seguem o padrão de fotografia de paisagem do século XIX devido a limites técnicos: foram tiradas antes de começarem as festas, às $18 \mathrm{~h}$, hora em que a câmera não podia operar por falta de luminosidade. O objeto central é sempre um símbolo - altares, cruzes, monumento - reafirmando o teor religioso da comemoração. Só numa aparecem populares, fixados pela objetiva ao acaso, nas extremidades da imagem.

Vale destacar que a Revista da Semana inaugurou, em 1900, a utilização de clichês fotográficos associados aos textos, suplantando a litogravura, o meio de reprodução de imagens mais empregado nas publicações ilustradas até então. O estilo da representação obtida com as lentes conservou, porém, a marca do olhar com que a realidade era enquadrada no século que findava. $O$ que as lentes não captavam ficava por conta da imaginação, insuflada pelos anúncios dos clubes e agremiações. Aí, com certeza, a animação, ao vivo, sobrepôs-se à qualidade estática das fotos e às marcações rígidas dos rituais religiosos.

\section{Balanços e expectativas}

No último dia de 1900 , os editoriais e artigos de fundo dos principais jornais e revistas do Rio formularam balanços e traçaram perspectivas dos tempos que se sucediam. A tônica foi a oposição ciência e espiritualidade. A primeira surgia ora como instrumento da libertação humana dos mistérios do mundo, ora como algoz de um tempo cercado pelo materialismo caótico. Pela verdade científica ou pela cla fé terçavam armas positivistas cientificistas e religiosos metafísicos:

"Ao som festivo de mil fanfarras, com profusão de flores e de luz, em grandioso côro, de louvôres e aclamações, vai hoje o mundo oferecer condigna recepção ao novo século. ... Século XIX, das luzes te denominam; grande, imenso é o teu ativo. Mas que importa não cumpriste tua missão! Logo no começo ... quizeste impor ao mundo a civilização ... . Pois bem! Em nome desta civilização ... os povos se digladiam com rancor, nacionalidades desaparecem no último instante da tua existência.

- Mas, dirás talvez, generalizando e facilitando os diferentes meios de comunicação, acaso não concorri para unir todos os homens sob a mesma comunhão de princípios e interesses? Não foi profunda e radical a mudança que efetuei nos usos e costumes, levando a quase todas as camadas sociais o conforto e o bem-estar...? Finalmente... não bastaria a influência preponderante da ciência nas coisas humanas ...

Ah! ... foi esta mesma ciência que te perdeu ... a orgulhosa ciência ultrapassou as raias do seu domínio e proclamou a sua infalibilidade; verdade só o que ela pudesse provar, falso tudo quanto escapasse aos seus métodos rigorosos, às suas regras, às suas leis! Destruindo, sem substituí-las, as nossas antigas concepções religiosas ... .

Ao respirar o último momento de tua existência, ó século, desiludicla das promessas da ciência, cheia de contrição, a humanidade inteira volve-se em fervorosa fé para seu Deus e criador! "M. (Cidade do Rio, 31.12.1900, p. 2).

Na coluna ao lado, outro cronista confessava, com mais otimismo, que ia sentir saudades dos 1900 , e que via à frente "cores claras, nuanças risonhas e céus radiosos". Oportunista, pedia ao ano velho duas palavrinhas de recomendação ao que se iniciava: "Olha, rapaz, trata bem o B. C., cronista da cidade, ouviste?" 


\section{REVISTA DA SEMANA}

Edição semanal illustrada do JORNAL DO BRASIL

Redactor-gerente, DR. CANDIDO MENDES - Redactor-ohefo, DR. FEANANDO MENDES DE ALMEIDA - Director-technico, GASPAR DE SOUZA

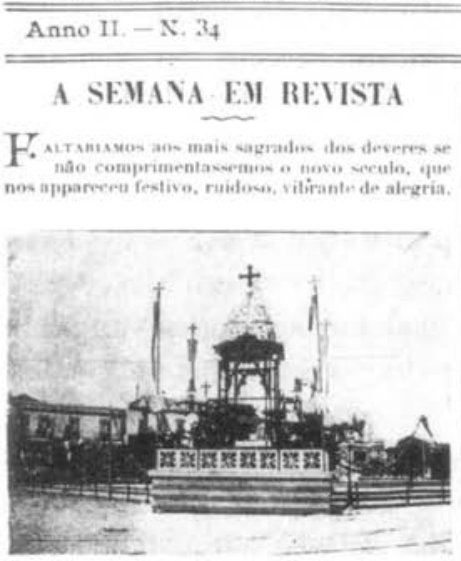

o M.TAn Do set.

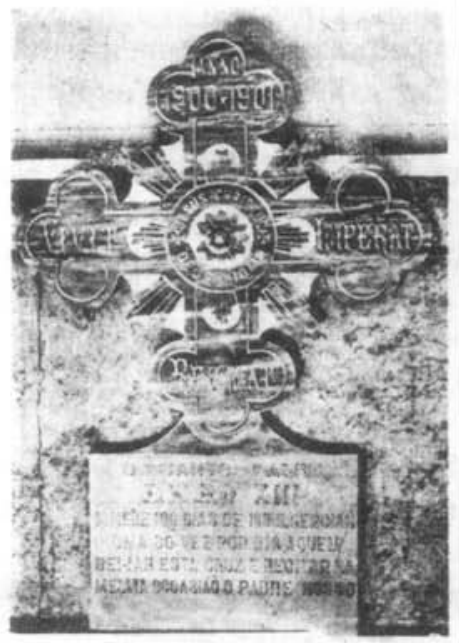

Crux conmemorativa da passagen do veculo

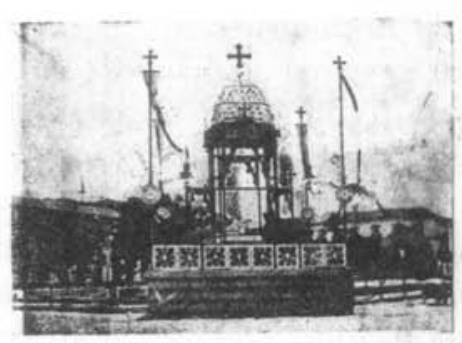

O ALTAR DO NORTE.

\section{DOMINGO, 6 DE JANEIRO}

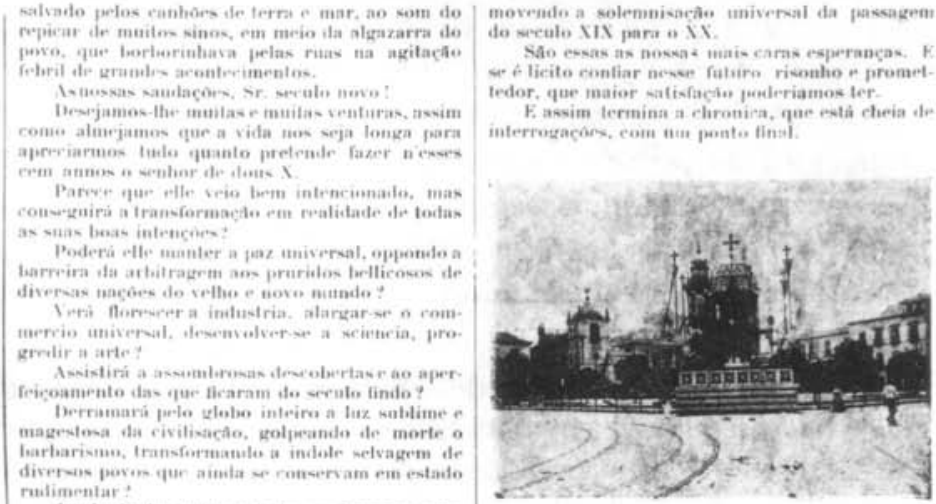

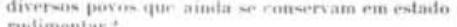
Implantara

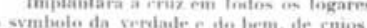

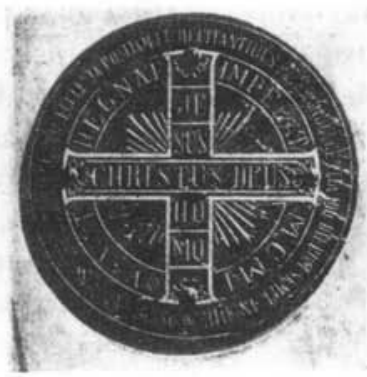

Crue commemorativa da pasangem do seculo

gotteja o sangur de Jesus, como orvalto que

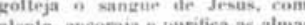

SAo estas interrogrativas qur constituirho os problemas de futuro, cujas evolucoes queriamos probtrmas do futuro, cujas wo decobrimento da incognita de cada um, até o terme final desses

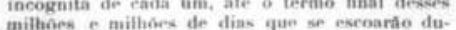

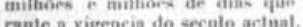

rante a vigeneria do sweuto artual. Talvez Arja isso impossivel: naso nos é dade
ambicionar a venturn de Mathusalen, nem confiar que as nowsas forcas physicas possam impedir o

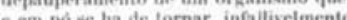

e em po se ha de tornar, infailivelmente,

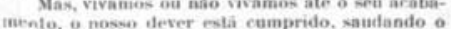

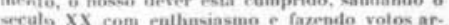
dentes para yue elle pas sua passagem marque a

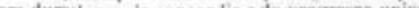
saes.

So the pedimos, em recoinpress, um pequenino faver: gue nos proteja, que nos de muito socego de espirito, muta saude - todas as venturas que scia Iicito pedir.

ger-the-a facil lazel-o, imitande o seculo morto. que no estertot das ultimas agoaias ainda se sentiu com anime pars azitar o mundo inteiro quer com os ultimos wuceeswos da guerra sul-africana, onde o beroisme gust ifefesa da patria ehrgon ao delirio, quer pela attituete gloriosa da Kirrja, pro-
Numero: 5oo réis

moxendo a solempisacâe universal da fascagen IX para 6 XX

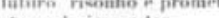
to pontu tind

O MLTAR DE LESTE

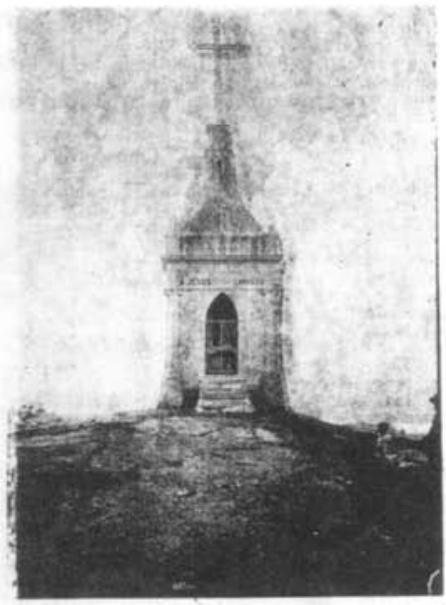
Monumento commemorativo da passagem do seculo

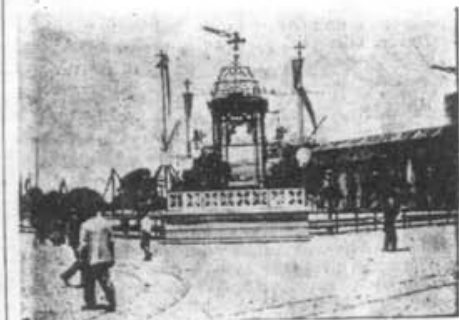

o AtTAR DE OKSTE

Fac-símile da prımeira página da Revista da Semana de 6.1.1901. 
O editorial estampado na primeira página, do Cidade do Rio, dirigido por José do Patrocínio, aproveitava o balanço do século para criticar. o governo de Campos Salles. A história recente do Brasil era apresentada como uma sucessão de conquistas realizadas por governantes honestos, bons e justos; o século XIX, como tempo de engrandecimento nacional. O passado era mitificado para aguçar a crítica ao tempo em que agia o articulista. Sobretudo esta: o presidente não respeitava a soberania do Congresso, pois não mandava uma guarda de honra para homenagear a última sessão do século. $O$ autor atacava, também, os desmandos da polícia que atentava contra a vida dos cidadãos "a tiros de revólver". (op. cit., p. 1).

A Revista da Semana (ano I, $\mathrm{n}^{\circ}$ 33, 30.12.1900, p. 1) fez um balanço dos fatos internacionais que marcaram o século XIX, compondo o texto com a oposição luzes/ trevas. A primeira era assegurada pelo conhecimento que se traduzia em descobertas científicas; a segunda era fruto, principalmente, da barbárie política. Razão e moral opunhamse como emblemas de um tempo que se iniciava sob a égide do pensamento racionalista:

"...A par de maravilhosas descobertas ... tivemos a carnificina de Sedam; se o gênio de Victor Hugo assombrou a humanidade, o punhal traiçoeiro de Caserio Santo feriu de morte o coração da França e enlutou todos os povos; se o catolicismo na Itália, depois da tomada de Roma pelas tropas garibaldinas, atingiu seu apogeu ... o revólver de Caetano Bresci ... fez tombar o corpo do monarca magnanimo, Humberto I ... se as forças aliadas procuraram implantar a civilização na China, ao mesmo tempo se combinam para a partilha daquele imenso e rico território; se entre nós realizou-se entre flores e entusiasmo indescritível a grande reforma da extinção do escrava-gismo, mais tarde foram ensopadas de sangue as ilhas verdejantes da

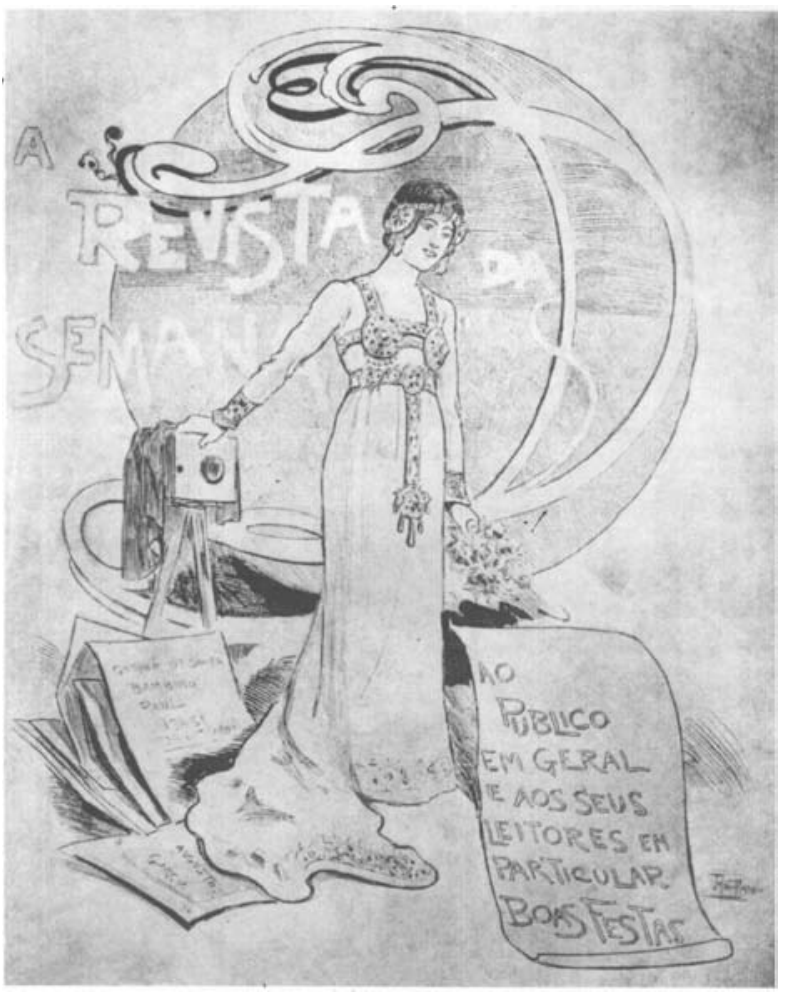
Guanabara... . Século de luzes e trevas! Digamos a ele adeus, sem saudades. Que o outro, cujo início será na próxima terça-feira, derrame sobre o orbe os benefícios da civilização, como outrora caiu do céu o maná delicioso que alimentou o povo de Moisés".

$\mathrm{Na}$ imagem a esquerda, o passado neoclássico é representado pela indumentária da jovem musa (pode ser a imprensa) e o futuro art nouveau, pelo globo ao fundo e a auréola que envolve a figura. A câmera simboliza a modernização da imprensa e a criação de novo padrão visual associado ao mito da verdade fotográfica. Abaixo dela, num maço de folhas de desenho, constam os nomes de caricaturistas e colaboradores da revista. Ao combinar o passado e o futuro da expressão visual, valorizando a técnica, a ilustração sintetiza a forma contraditória de expressão do fim de século (Revista da Semana, 30.12.1900, p. 1). 


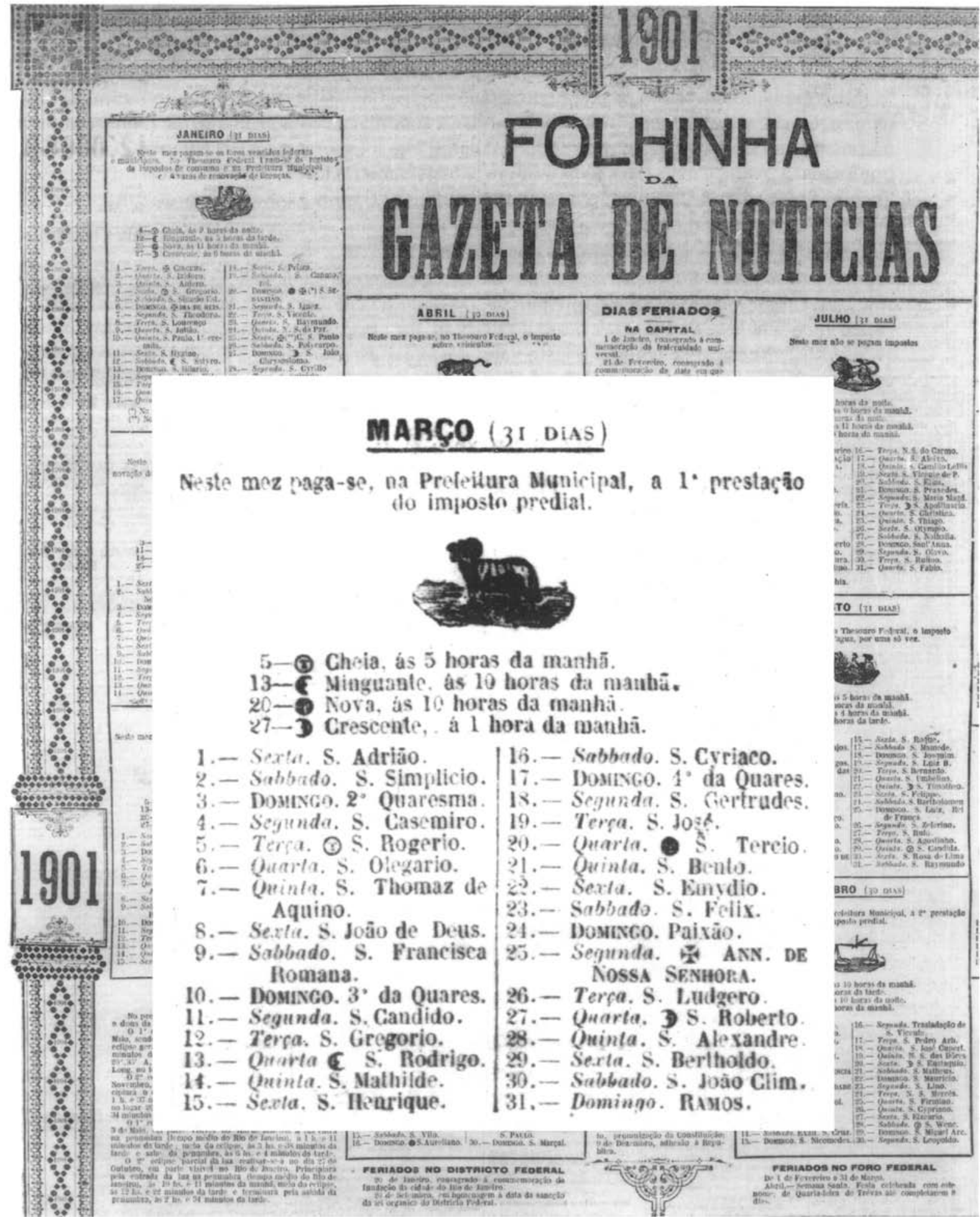

Parte do calendário publicado na Gazeta de Notícias, em 1.1.1901. Indica feriados, dias santos, fases da lua, impostos a pagar, tabela de câmbio etc., associando aspectos religiosos e laicos da vida cotidiana. Março destacado. 
Esperança é o tema do editorial de O Paiz assinado por Valentim Magalhães, 'No limiar do século XX', no último dia de 1900:

“...todos esperam do século próximo, do século novo a felicidade que não encontraram no extinto. Esse sentimento repetido todos os anos ..., centuplica de intensidade, naturalmente, na passagem de um para outro período secular. É ela, a esperança, a deusa abençoada e boníssima, a maior, a mais bela, a mais nobre, a mais pura das forças misteriosas do espírito. Por um fugaz instante, por sobre a superficie turbada do mundo, empoçada de sangue e lágrimas, arrasada e combusta pela guerra, talada pela peste, ... faz crer que todo o mal se ha de converter em bem, toda a Terra desabrochará em sorrisos...

Esperemos, sim, contemporâneos e amigos meus, esperemos o século XX. O que hoje morre, solitário e abandonado ... foi, ao que parece, o século da ciência, das luzes, da civilização. Esperemos que esse venha a ser o seculo do bem. Está por se fazer ainda o inventário do século XIX... Verificar-se-á então o justo valor das conquistas científicas para estabelecer o único verdadeiro fim desse balanço: o real proveito que trouxeram à felicidade humana os progressos e reais triunfos da ciência. Terá ganho muito a humanidade?"

A fotomontagem entitulada 'Fotografia profética do que será o Rio de Janeiro no $\mathrm{V}$ centenário' (Revista da Semana, 6.1.1901) vinha acompanhada do seguinte texto:

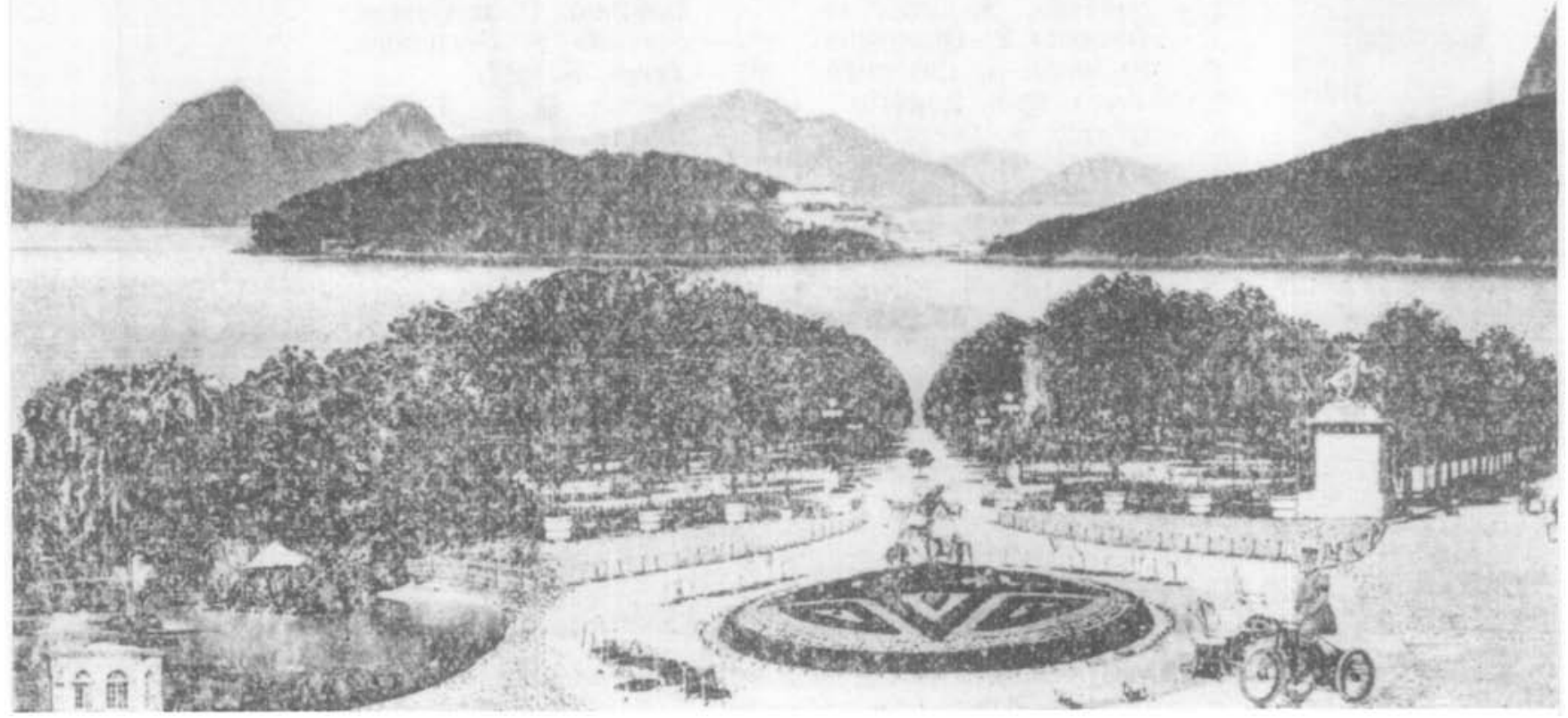


"A famosa avenida parisiense dos Campos Elíseos, com o seu Arco do Triunfo na extremidade, fará triste papel ao lado das nossas incomparáveis avenidas a se terminarem na maravilhosa baía de Guanabara, orlada de píncaros recortados, inçada de ilhas dos amores, um mar de esmeralda sob cúpula de eterna safira, águas levementes franjadas de graciosas crispações pela brisa fagueira. ...

À barra, o gigante de pedra continuando a dormir o seu sono milenar: em volta, no anfiteatro, soberbos cais de cantaria desde a base do Pão de Açucar até a Praia do Caju; bordados por uma teoria de palácios comerciais e industriais feitos de granito, combinando o efeito da beleza arquitetônica ao de indestrutível solidez.

Da rua do Ouvidor restara apenas a memória: os homens de 2000 d'ella se lembrarão como hoje nos recordamos do Largo do Rocio quando Tiradentes foi enforcado ou do campo da Honra no tempo das lavadeiras. Estará transformada em vasto e belíssimo boulevard, indo da praça da República ao mar, ladeado de admiráveis construções, hotéis monumentais, luxuosos cafés com terraços, armazéns de modas à feição do Bon Marché. Para evitar aglomeração e embaraço (pois a população fluminense contará então um milhão e meio de almas) haverá no grande boulevard caminho para os pedestres separado do dito para as carruagens.

Ao meio, em um largo, ver-se-á a estatua de um grande brasileiro que ainda não está nascido, estátua esculpida por um genial artista que igualmente ainda vai nascer.

As moças do século futuro saberão pisar com mais elegância e falar com mais correção. Das suas lindas bocas não se ouvirá, como hoje, esse fraseado tão desagradável: vi ele, que home, me deixe, tá bom etc.

Sabem como se chamará o Sacco do Alferes?

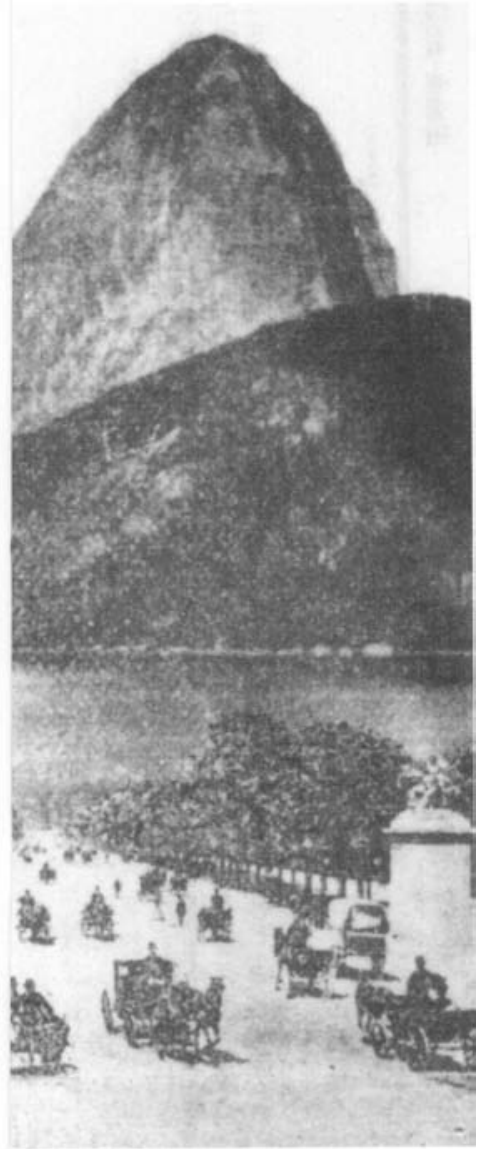

Avenida das Rosas! Um dos passeios prediletos da nossa aristocracia...

Botafogo, com a sua sublime enseada, atrairá turistas do mundo inteiro; se embevecerão na sua contemplação.

O último caso de febre amarela terá ocorrido em 1940, há sessenta anos. Os nossos netos exclamarào: Que moléstia seria esta que produzia vômito negro e tinhá nome de amarela? Nossos avoengos eram uns esquisitórios!

A tuberculose pulmonar tambem haverá passado à cesta das velharias. Os postevos dirâo: Como estava a ciência atrasada há cem annos! Morria-se de tísica! Ora veja! Morria-se de tísica!! Que médicos ignorantes os do tal século XIX.

Mas o nosso tempo encontrará defensores, pois sempre existirão particlários do passado, apologistas do bon vieux temps: os velhos do ano 2000 hào de alegar a pureza clos costumes dos homens do ano de 1900, a sua sincericlade, o seu patriotismo, a sua vida patriarchal, o seu desinteresse (exatamente o que nós hoje dizemos dos homens de 1800 e o que os de 1800 diziam dos de 1700 ).

Le bon vieux tempsé sempre o melhor, embora não prestasse para nacła. ... Em suma, ao se comemorar o quinto centenário da descoberta do Brasil, a cidade do Rio de Janeiro terá atingido a um grau estupendo de progresso e de refinada civilização. Depois da revolução francesa, realiza-se mais progressos em um único século do que se realizavam em dez séculos anteriores à grande data humana.

Todavia, não nos iludamos sobre os progressos morais. Os brasileiros de dous mil padecerão dos mesmos defeitos e vícios, das mesmas paixões que os brasileiros de 1900. Na política, haverá intrigantes, nulidades espavezadas, excelsos engrossadores. No comércio e na industria, altos ladrões, açougueiros para vender quilos de 600 gramas, fabricantes de vinho sem uva, de manteiga sem leite. Na imprensa, escritores analfabetos, jornalistas venais. Nas eleições, 


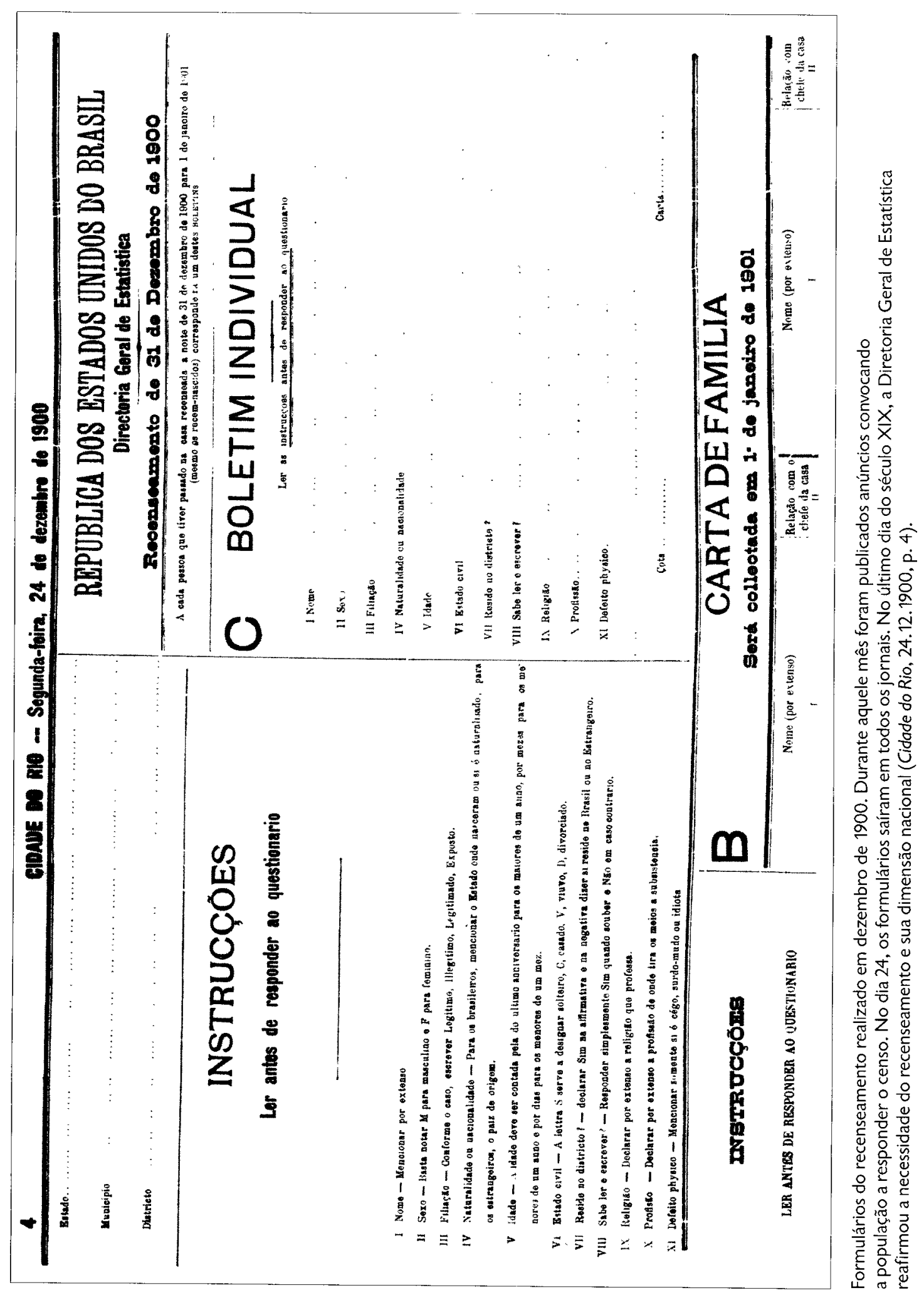


mesas faciosas, apuração a bico-de-pena, defuntos votando, câmara depurando, oposição protestando, e finalmente tudo ficando em paz.

A municipalidade do ano 2000 continuará a não ter dinheiro para pagar aos seus empregados, apesar de sua renda de 250 mil contos. O prefeito contrairá empréstimo para saldar dívidas, e por isso será considerado benemérito funcionário. ... E um jornalista descontente escreverá no final do seu artigo de fundo: 'O país vai à garra! Caminhamos para um abismo.'

(Nota final: Das cousas feias do Rio só existirá em 2000 o canal do Mangue. Não houve engenharia capaz de dar cabo d'aquela abjeção).

\section{Caricaturas}

As caricaturas formam um capítulo à parte em meio ao material que documenta a passagem do século. Humanizam o tempo, pespegando nele atributos que o caricaturista concebe a partir do modo pessoal como vive e percebe o curso desse tempo. A mensagem nem sempre é engraçada, mas é sempre crítica.

O Jornal do Brasil é um veículo fundamental para se avaliar esse tipo de representação devido aos trabalhos de dois notáveis artistas: Julião Machado e Bambino. Ao responder à acusação de que fustigava insistentemente o poder, o primeiro, em 'Mea culpa' (3.1.1901), fornece um excelente 'negativo' do papel desempenhado por esta forma de expressão na virada do século:

"Reconhecendo que temos incorrido em gravíssimo erro caricaturando os altos poderes públicos, perante os quais cada contribuinte tem o indeclinável dever de se acocorar respeitosamente pasmado; reconhecendo que a caricatura, que foi especialmente inventada para lisonjear os grandes, deve ser doce como uma bala de altéia: reconhecendo mais que a missão da caricatura é altamente melindrosa, porque ela tem o dever de incensar os que triunfam, vaiando os que tombam na liça da vida (liça da vida, começo bem o século!); reconhecendo, finalmente, que muito mal avisados temos andado em rir dos 'importantíssimos', porque - como muito bem disse o sr. D'Argenton: a vida não é um romance - , resolvemos de hoje para o futuro tomar briosamente o lugar a que temos direito entre os da claque. Em presença dos grandes e ao seu menor gesto - quer esse gesto seja apenas para abafar espero, a nossa atitude será conscenciosamente esta: aplaudir e pedir bis. Não mais o nosso lápis, outrora mágico, hoje apenas mercantil, procurará a nota humorística nas pessoas e nos acontecimentos graves. Não mais cometeremos a tão condenável irreverência de apresentar ao público os homens eminentes em mangas de camisa. Que o céu nos dê um vozeirão de estrondo para que possamos viver amodorrados na simpatia e na admiração de pessoas tão circunspectas e que alguns julgam prejudiciais, se não inúteis. Amém!"

Que estas imagens curiosas sirvam ao leitor, que está em vias de testemunhar nova virada de século, como pistas para pensar o tempo como representação. As imagens decantadas pelo tempo podem ser vistas como emblemas que condensam e iluminam as maneiras diversas como cada época se apropria do passado, do presente e do futuro. Contraditoriamente, conservam uma espécie de atemporalidade, apesar de estarem inscritas no devir inexorável que a tudo e a todos arrasta desde o que já foi ao que ainda não é

Ana Maria Mauad

Doutora pela Universidacle Federal Fluminense (UFF), onde é professora da Pós-graduação em História e do Laboratótio de Iconografia Campus do Gragoatá, Bloco O, sala 201

Niterói - RJ Brasil 


\section{FONTES}

Títulos da Biblioteca Nacional - Seção de obras raras Almanaque Laemmert; Derby Club RJ; O Apóstolo; Balanços Gerais da União; O Brazil Médico; Cidade do Rio; D. Quixote; A Estação; Jornal do Brasil; Jornal llustrado para a Familia; L'Etoile du Sud; O Fluminense; Gazeta de Notícias; Gazeta de Petrópolis; A Imprensa; O Lynce: Periódico Crít. Lit. Rec. Not. (Macaé); O Paiz; O Palpite da Época; O Popular (Petrópolis, 1899-1900); Reformador- Órgão Evolucionista (outubro, 1900); Retrospecto Comercial do Jornal do Commercio; Revista Catharinense (jan.-abr.-mai., 1900); Revista da Semana; Revista da Sociedade de Geografia do Rio de Janeiro; Revista do Club de Engenharia do Rio de Janeiro; Revista do Instituto Polythécnico Brasile; The Rio News; O Século (out. 1881; 1906-16; 1908-10); O Século XX, Órgão Scientífico e Literário (1885); Tribuna Operária (out.-nov., 1900).

Títulos da Biblioteca Fundação Casa de Rui Barbosa — Coleção Plinio Doyle Revista Contemporânea; Ilustração Brasileira; João Minhoca; Revista Moderna; O Ferrão; O Rio Nu

\section{Ficha técnica}

Reproduções fotográficas:

Claudio de C. Xavier/Divisão de Microrreprodução/Biblioteca Nacional

Edição:

Jaime Benchimol/Ruth B. Martins

Tratamento das imagens digitalizadas:

Fernando Vasconcelos

Agradecimentos:

Jornal do Brasil, que autorizou a reprodução de fotos e caricaturas

Maurício Vasques, que ajudou na pesquisa dos jornais 


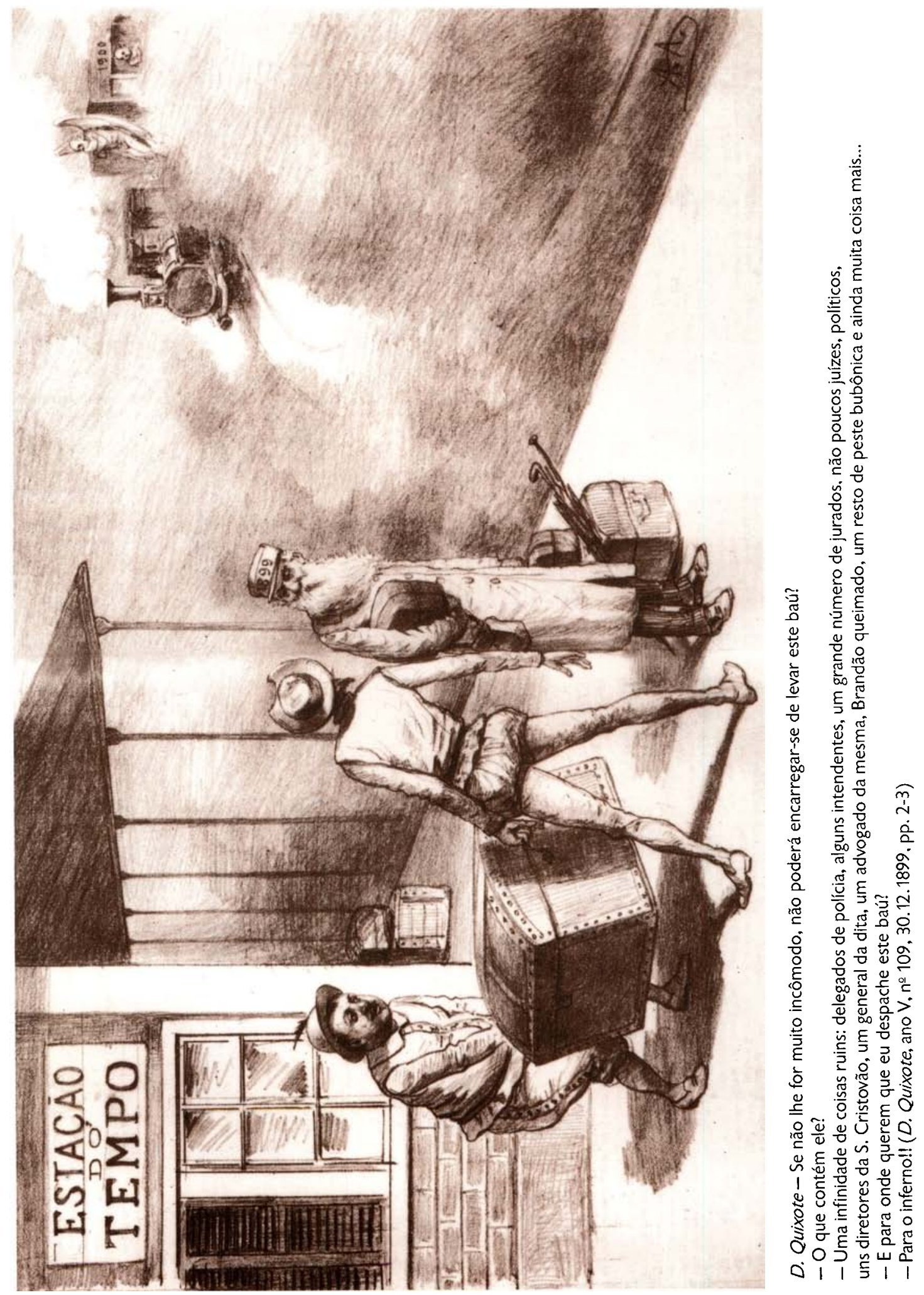




\section{COISELHOS DE UM PAP AO SEU FILHO \\ ARTE DE BEM VIVER NO SECULO XX JUIIA口O MAACIADDO}
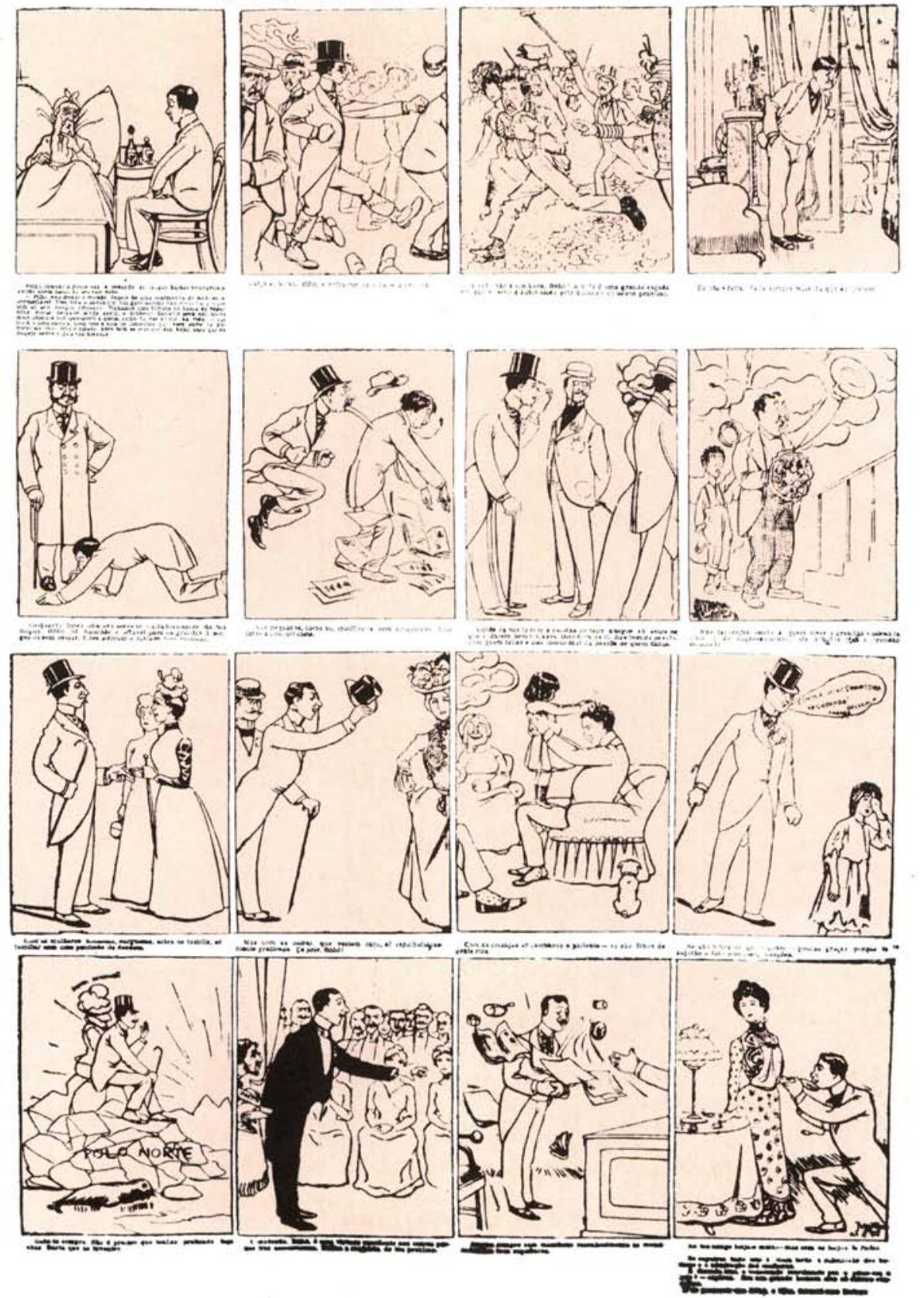

No primeiro quadro, o pai moribundo dá os últimos conselhos ao filho. Nos quadros seguintes, este se utiliza de artimanhas para sobreviver. É uma crítica ácida ao arrivismo, ao oportunismo e aos puxa-sacos em geral. Em um dos quadros lệ-se: "Enquanto fores obscuro serve-te cuidadosamente da tua língua Bobó. Sê humilde e afável para os grandes: Lisonjeia-os sem cessar. Eles adoram o calçado bem lustroso." Em outra: "Com crianças sề carinhoso e paciente - se são filhos de gente rica" (Jorna/ do Brasil, 2.12.1900). 


\section{PEILA moreatidDade!}

Episodios da policia chineza no estertor do seculo XIX, por JULIÁ machado
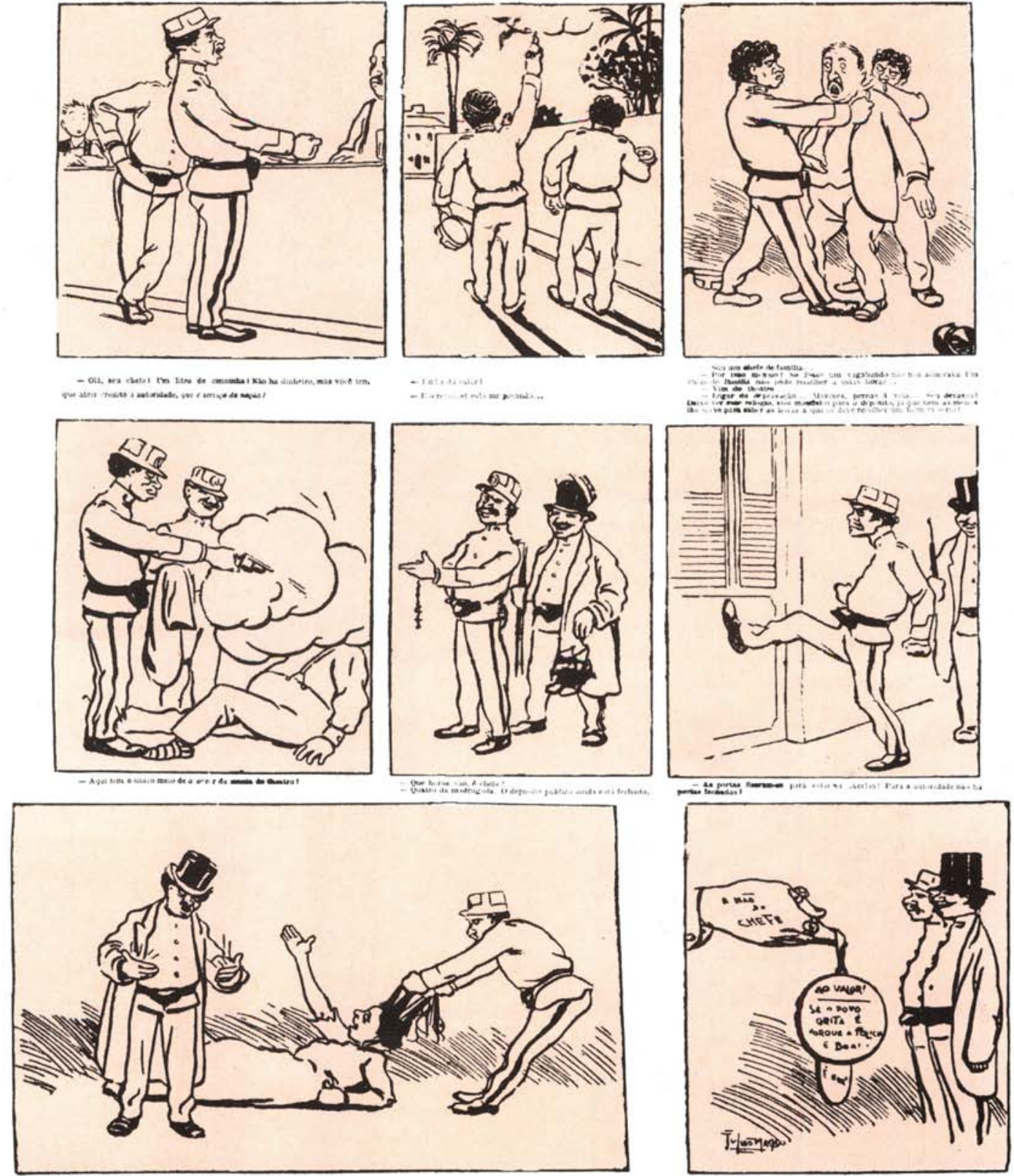

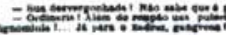

Esta caricatura documenta um problema que sobressaía nos jornais: a violência policial no Rio de Janeiro. Para evitar problemas com a censura, a polícia é apresentada como 'chinesa', mas os guardas tomam "caninha", faz um calor desgraçado e, no "lugar de depravação", dança-se o maxixe (Jornaldo Brasil, 23.12.1900). 


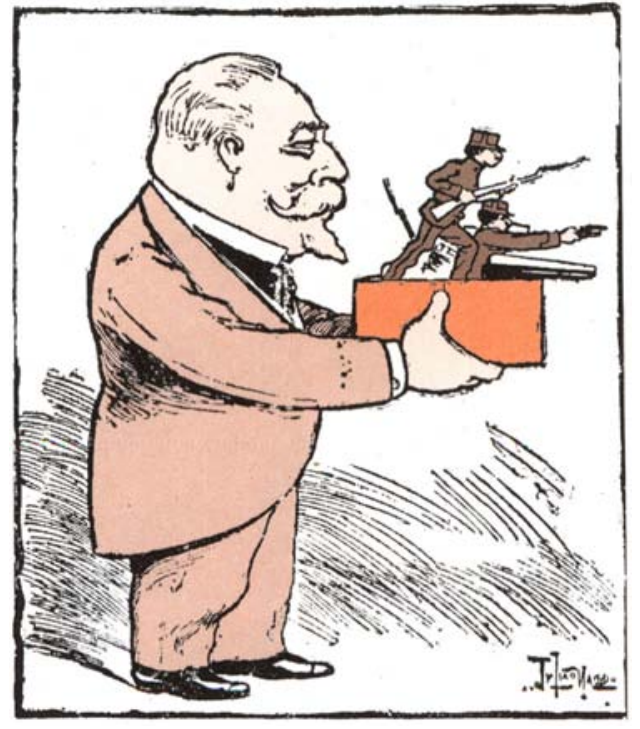

'Últimos restos do século'. Mais uma vez, Julião Machado critica a violência policial. Da caixinha de surpresas saem guardas atirando. "Festas para as crianças grandes que gritarem muito", explica a legenda (Jornal do Brasil, 27.12.1900).

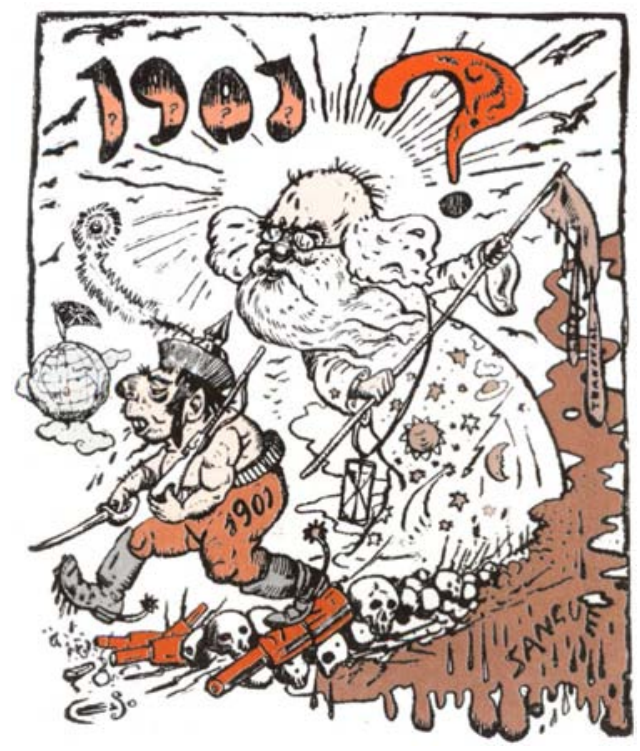

'O novo ano', por Celso Hermínio. “O velho tempo diabólico dá-nos um novo ano que é um monstrınho, bem parecıdo com o falecido pal -o 1900 - o fatal ano das guerras do Transvaal e da China. O novo ano, que parece um pequeno Átila armado, vem pisando sobre caveiras"

(Jornal do Brasil, 30.12.1900, edição da manhã, p. 1).

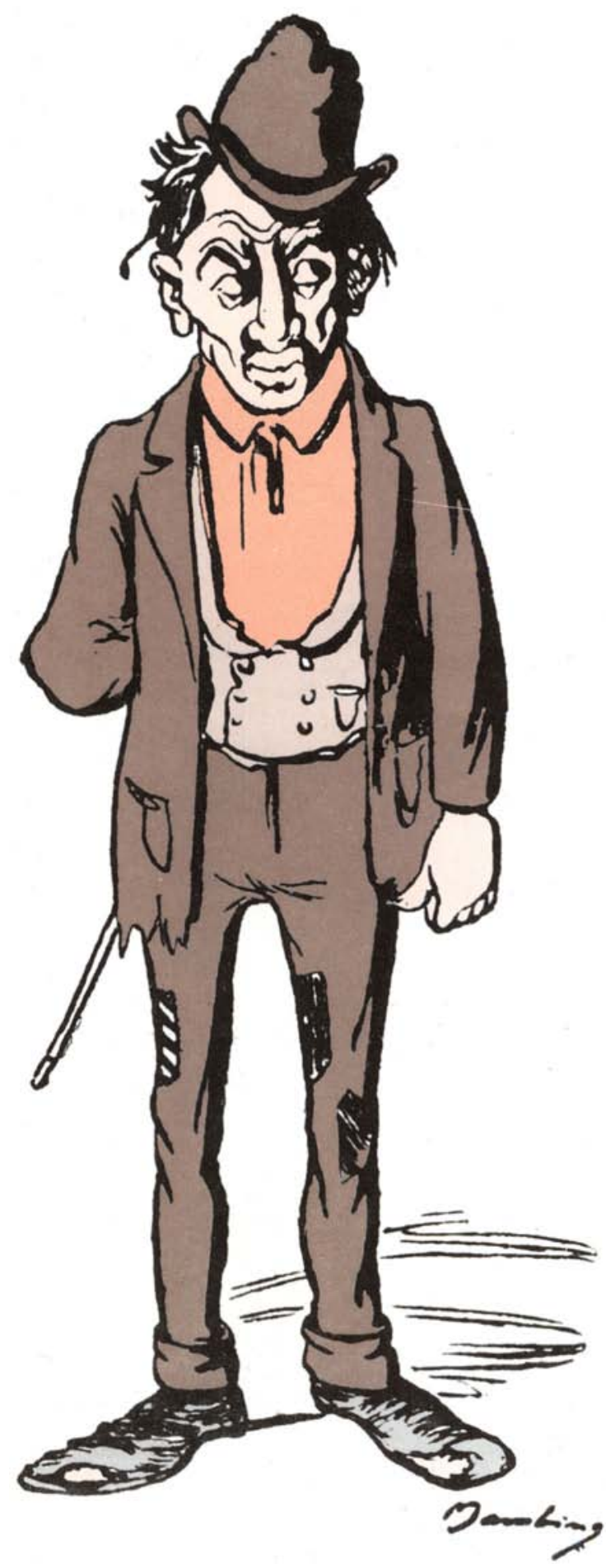

'O novo seculo', por Bambıno. Homem roto e desanimado com a legenda: "Monólogo de um triste..." (Jornal do Brasil , 30.12.1900, edição da manhã. p. 1). 


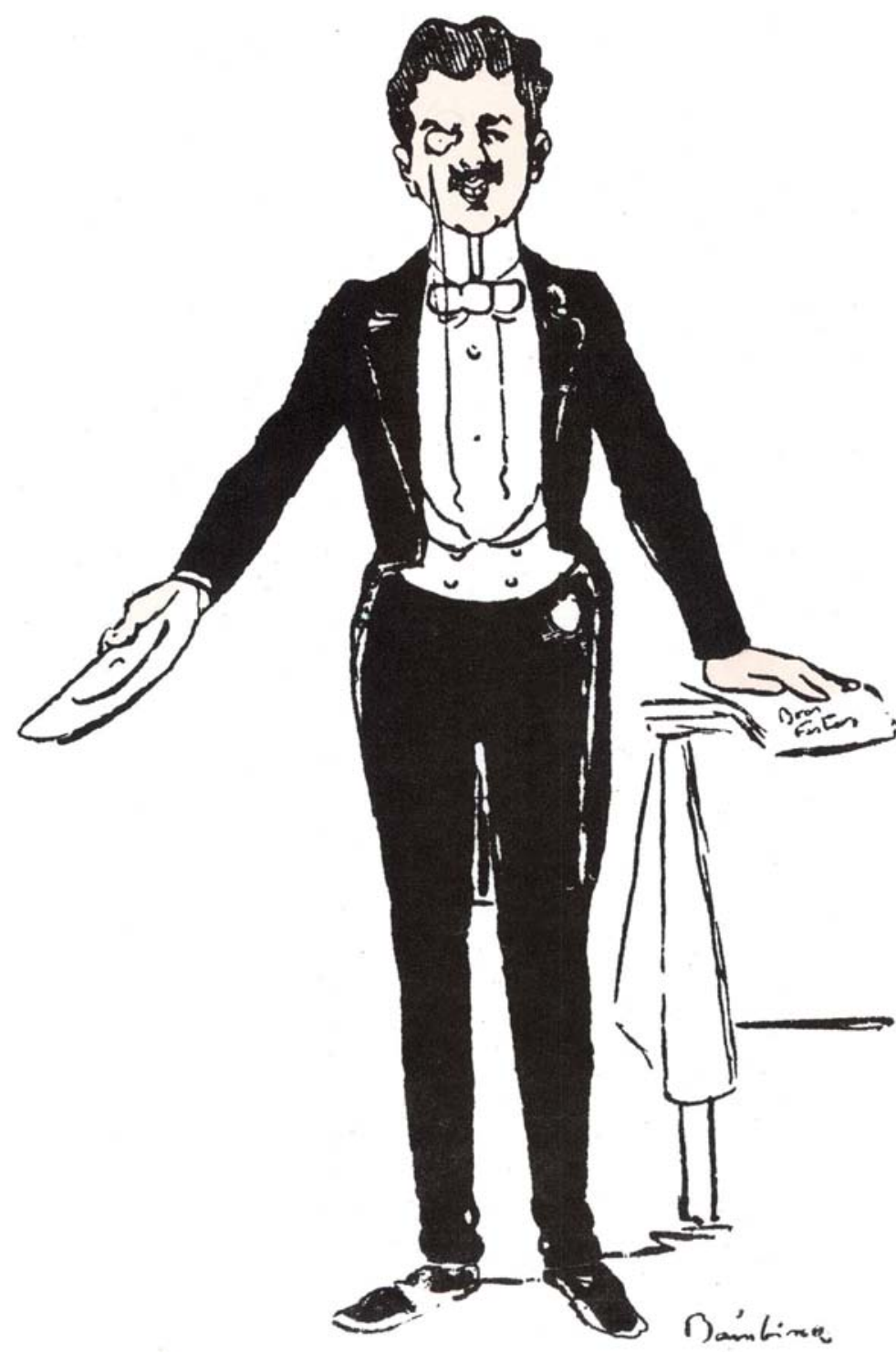

'O Jornal do Brasil, por Bambıno, é representado como um senhor de fraque e monóculo que diz na legenda: "A todos os meus caros leitores desejo muito boas saidas e melhores entradas! $E$ até o século que vem. Não se esqueçam que amanhã estou chic a valer. Vejam a edição matutina e digam-me deposs se eu minto" (Jornal do Brasil, 31.12.1900, edição da manhã, p. 1).

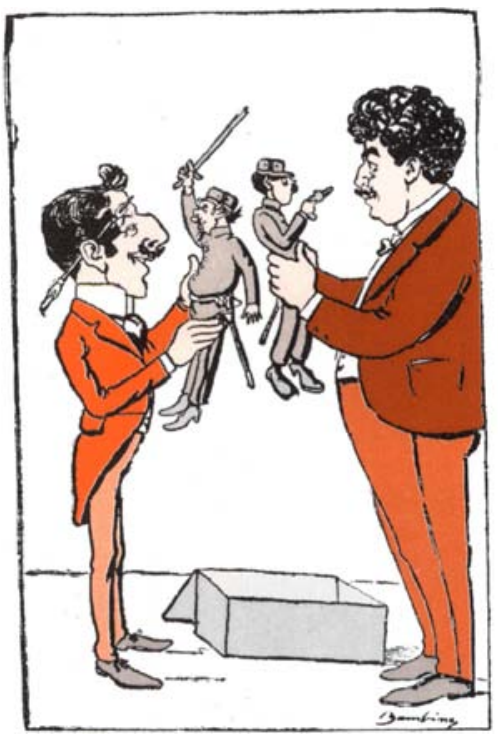

'As nossas festas', por Bambino que, na legenda, explica: “Julião (Machado) e eu recebemos como presente de festas estes bonecos que ai estão acompanhados do seguinte recado - "Vocês acaba mais é pintando os boneco nas parede do xadrez - Assinado: $O$ Refle. Não é preciso dizer: tivemos um sorriso amarelo" (Jornal do Brasil, 30.12.1900, p. 1).

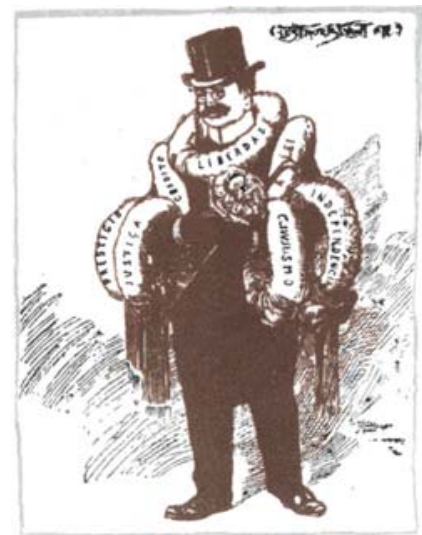

llustração de Julıão Machado. Senhor bem-vestido, com a cartola típica dos políticos, porta coroas de flores, nas quals estão inscritos princípios como prestígio, justıça, crédito, liberdade, cıvilismo, lei e independência. "No dia de finados, vou ao cemitério da Patria prestar homenagem aos meus finados", lê-se na legenda (Jornal do Brasil, edição da manhã, 4.11.1900) 


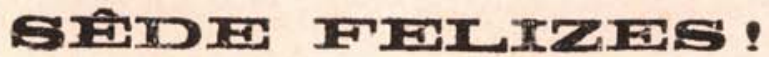

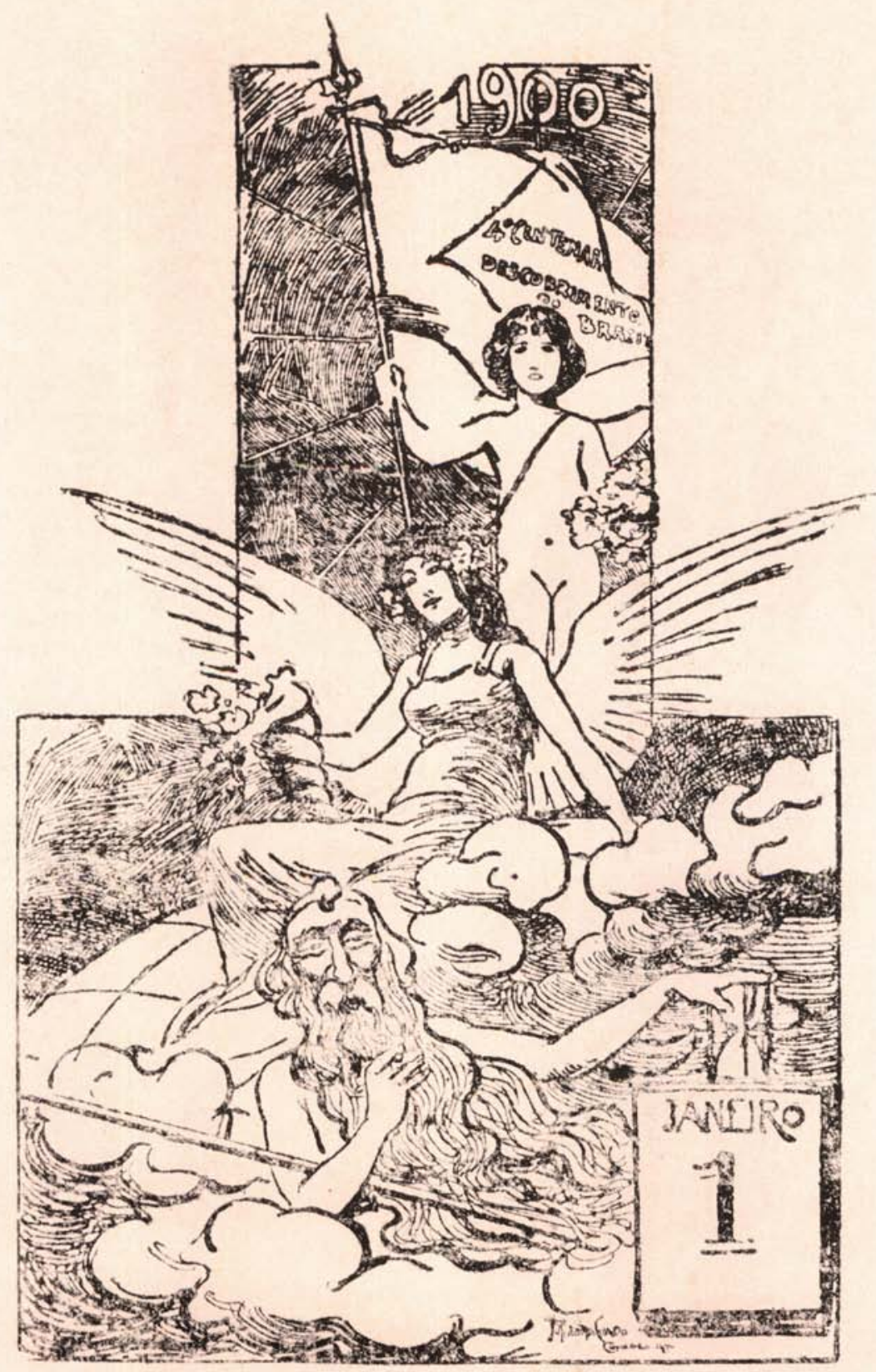

Ilustração de Julião Machado ocupando um quarto da primeira página da Gazeta de Noticias. O tempo, de barbas brancas, segura uma ampulheta, a fortuna, e o novo ano, representado por um rapazola desnudo, exibe bandeira com os dizeres: "4ํㅡㄹ centenário do descobrimento do Brasil". A legenda diz: "Sêde felizes! - 1900, o jovem e gracioso ano (é preciso lisonjeá-lo) traz a chave que, segundo uns, vem fechar o seculo XIX e, segundo outros, abrirá o século XX. Que ele abra um período novo de prosperidades e de alegrias para a Republica e que a fortuna o acompanhe, desvendada, para que vos possa enxergar a todos!" (Gazeta de Notícias, 1.1.1900). 


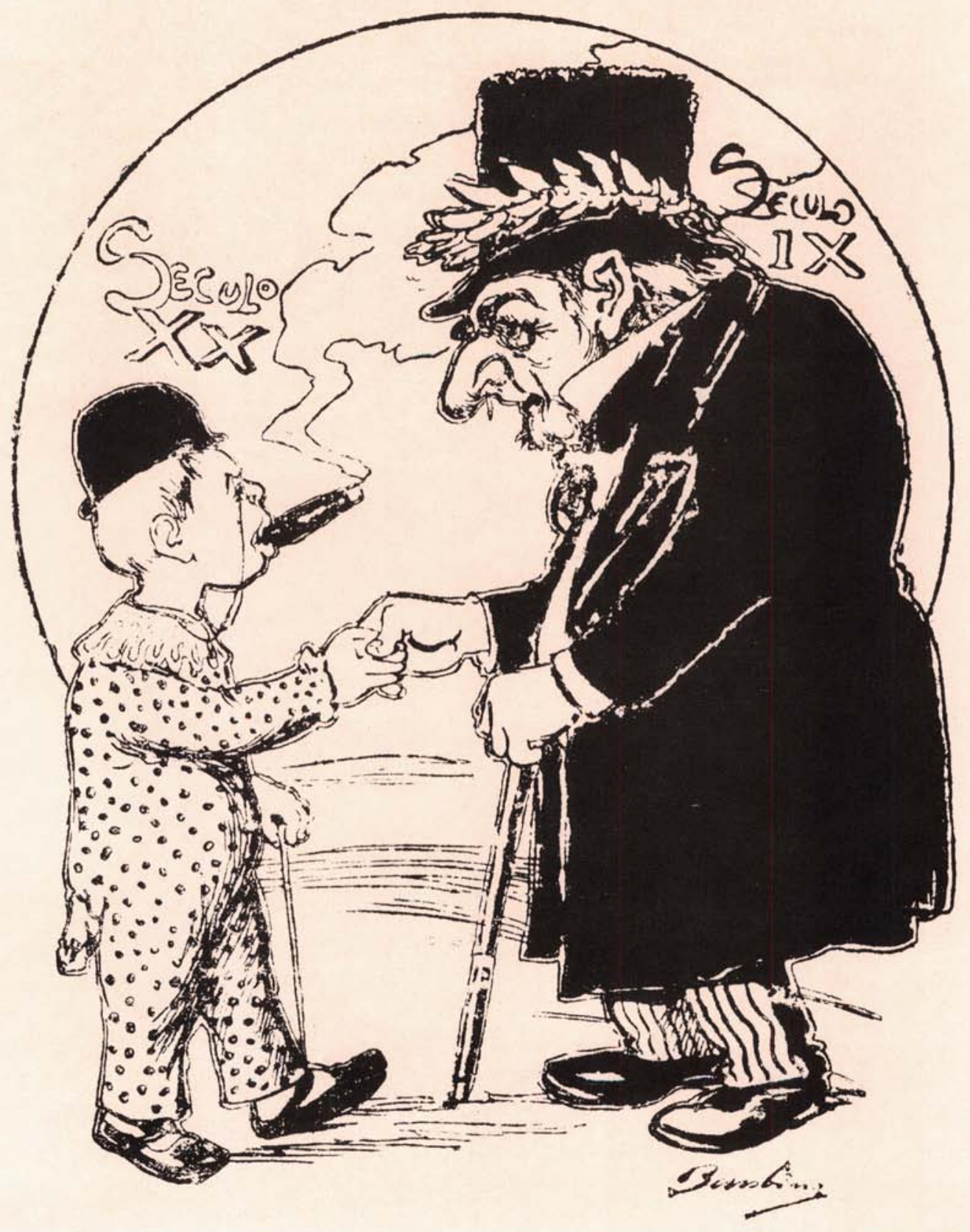

'Os dois séculos', por Bambino. O novo é um menino astuto, com monóculo e charuto: "Adeus meu pirralho. A herança que te deıxo é grande! Vê la o que fazes... Muito obrigado, seu século das luzes... elétricas" (Jornal do Brasil, 1.1.1901, edição da tarde, p. 1). 


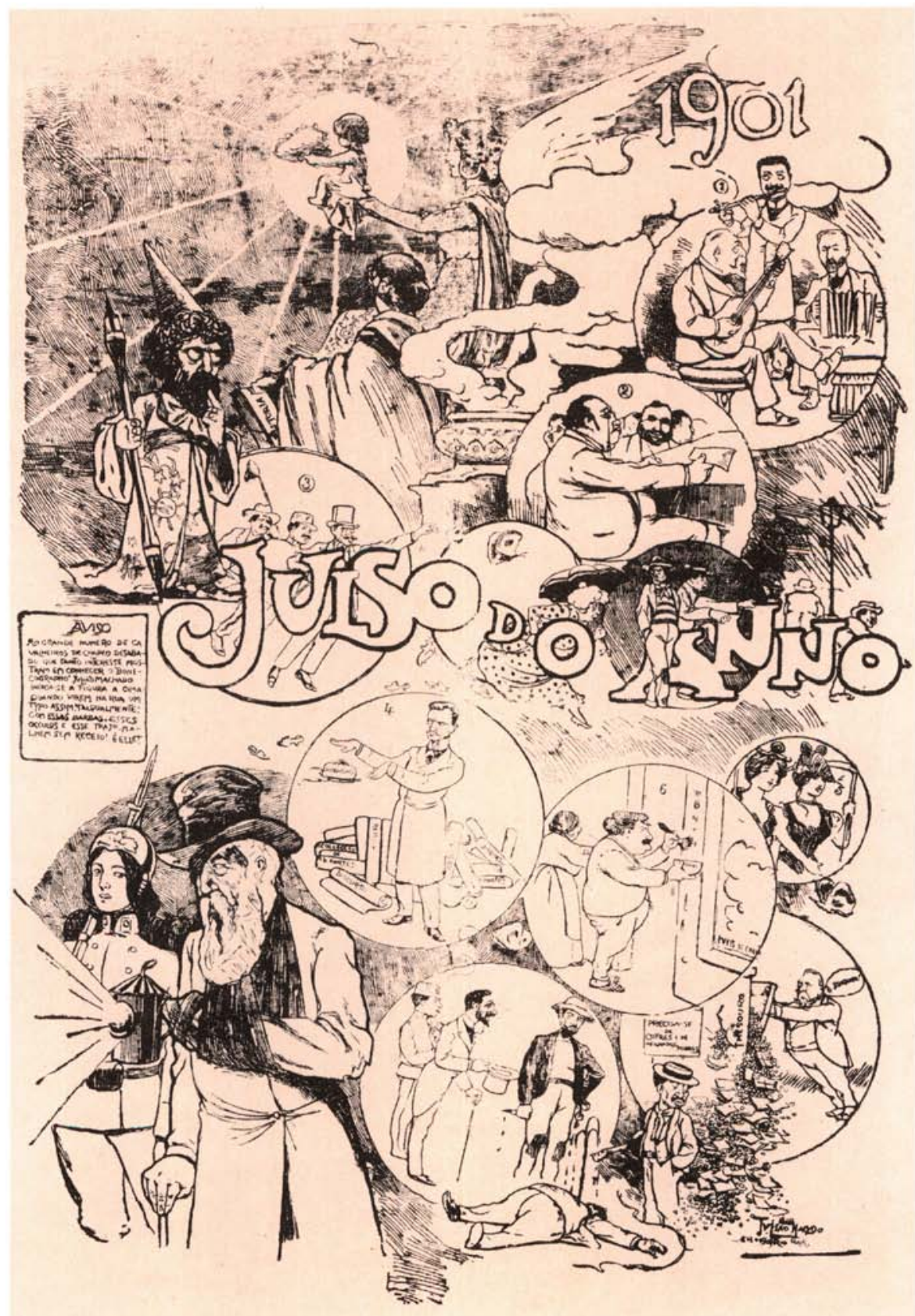

'Juízo do Ano de 1901', de Julião Machado. Na parte superior esquerda, uma mulher alada apresenta o ano-criança. Ao lado, outra mulher segura um livro com a palavra "História". Um mago - o próprio Julião - observa a cena. As demais são "Previsões do mago russo 'Schwozptski”". Na primeira, o presidente afirma que não irá a Buenos Aires (a viagem, em 1900, foi muito comentada). A segunda prevê o fim dos impostos e a queda do custo de vida. A terceira mostra a polícia caçando borboletas, depois de ter eliminado o crime. Na quarta, os deputados trabalham, sem nada receber. A quinta fala da erradicação da peste e da febre amarela. A sexta exibe proprietários de imóveis dourando e colocando pedras preciosas em suas casas (todos teriam casa própria). A sétima, prevendo o fim da violência policial, mostra interrogatório civilizado. A última deseja "abundância do tesouro nesta terra de prosperidade". Na legenda, Machado declara: "Tudo leva a acreditar que o ano de 1901 terá muitíssimo mais juízo do que o que ontem deu à casca" ( Jornal do Brasil, 1.1.1901, edição da manhã, p. 1). . 